\title{
"SORRY" EXPRESS BY SENIOR HIGH SCHOOL STUDENT IN CIMAHI : SOCIAL CULTURAL EFFECT ON LANGUAGE
}

\author{
Risky Ramadhan ${ }^{1}$ \\ ${ }^{1}$ IKIP Siliwangi \\ ${ }^{1}$ riskyramadhan2598@ student.ikipsiliwangi.ac.id
}

\begin{abstract}
Language is tool that use by human for communicate, and as tool to support them as social creature. Language is used by human every day in every situation, that make language become interesting phenomenon. During learning and teaching process that happen in class researcher find out the phenomenon that student use word "sorry" in context of asking permission not context for asking apology or expressing sympathy based on . Methodology of this research is qualitative with descriptive design. The instrument that use is observation, researcher is do observation in classroom activity on the class, and data is find from utterance that make by student during classroom activity. The result of this research most of student use word "sorry" in context of asking permission not for asking apologize. To understand the bigger concept of word sorry better to use bigger subject in research.
\end{abstract}

Keywords: Sorry, Language, Culture

\section{INTRODUCTION}

Language is something that human use to communicate each other. in other word language make human to be a social creature. According to (Sirbu, 2015) language is necessarily a aid of communication in society. In the term of culture language is crucial aspect. Language has an important role so nowday language has phenomenon. According to Chomsky that language is a system of free formation, the rule and principle is stable, but the manner in which the principle of process are used is free and boundlessly varied even the interpretation and use of word concern of free formation. In other word language has limitless since the user of it also not limited by certain amount of number.

Phenomenon of language is change of language, that change is influence by the culture, social its self and other factor. In reality is load of phenomenon of language such as slang, jargon, and slogan. That is kind of language phenomenon influence by social its self. How the phenomenon of language influence by the culture its how the culture influence the language or language influence the culture.

Culture its something that people believe and always them do. But can change if something give influence to the culture. Now days the culture can influence the other factor or the other factor influence the culture. Example is how the culture influence the language, and the language influence the culture its self. Culture influence the language its like how the culture of Indonesia influence to the English language or, in other word culture is influence how people using the English language. Student is member of society that get influence from the culture to their language especially when they use English language. That happen because when student use their second language their mother tongue is easy to influence the second language and make some error. 
One of the phenomena that happen in classroom activity that do by student is use word maaf for asking the permission to other people, the student is more like use word maaf than word permisi to asking the permission. Something that student do is be culture in Indonesia from past until now using word maaf its more polite than permisi for asking permission. Now days that Indonesia culture is influence the language, or in other word that culture influence how the people speak English.

Reasercher find in reality now days that is in classroom activity, student of senior high school its using word " sorry " to asking the permission to other Pearson when they talk English, actually the grammar or the habit of British people its use word " excuse me" to asking permission. But the culture of Indonesia has been influence the originally of word "sorry" use for. That is phenomenon of language that transformation the purpose of word "sorry " from used for say apologize or to express sympathy, but for senior high school student word "sorry" have purpose to asking the permission.

The phenomenon that happen about utilizing word sorry for asking the permission because the influenced by Indonesia culture, make the other phenomenon of language appears. The phenomenon that appers is in semantic problem.

Semantic is study of language about real meaning or true meaning of word. According to Kreidler in (Holtgraves, Kashima, Kashima, \& Kidd, 2014) Linguistic semantics is the study of how languages organize and express meanings. And other definition semantic is the study of meaning in language Hurford \& Heasley in (Holtgraves et al., 2014) . From that definition is showe that semantic is study about true meaning of word. In semantic word "sorry " have meaning for express the sympathy or say apologize if someone do mistake in society to other.

Nowadays word sorry use for asking permission by senior high school student, when them talk English or Indonesia language it self. The gap that showed previous paragraph is show two phenomenon of language, if the people use sorry in English language the phenomenon its culture of Indonesia influence the English language. If the word sorry use for asking permission in English utterance or Indonesian utterance in conversation its mean semantic of the word "sorry" is gone.

that phenomenon almost be new culture in Indonesia, and its very important to be discussed and very interesting to be discussed, its why this article tittle is "Sorry" Express by Senior High School Student in Cimahi: Social Cultural Effect on language This article its can inform to other people and remind the people that originally word "sorry " is for apologize and express the sympathy and not for asking the permission. And also to find the reason why Indonesian people use word " sorry" to asking permission.

\section{True Meaning of Word (Semantic Meaning)}

Language is something that human use for communication, language it self is build from the sentence and sentence is build from the word, in other word, language is make form the word. Words are what we make of them, that much is true; however, it is often not recognized what they, in turn, reveal about us (Holtgraves et al., 2014). From that statement researcher can explain that language is make by word, when some word is use in wrong position it can be a problem for language because the meaning of the language that use will be change.

According to Dunai in (Grote \& Linz, 2003) in him lecturer not when he course in general linguistic the starp of what we know now as the scope of linguistic can be fix in Saussure's deft and enlightening study of language. (1916) and semantic is the abstraction of word meaning. 
The true meaning of language or true message that can know by reader or receiver will be change if the semantic meaning is change so the meaning of language also change.

According to Seassure in (Holtgraves et al., 2014) synchronic (the state of a language at a fixed point of time) and diachronic (change in a language over a period of time). That statement show as that language is cant change because something influence because language is fixed point of time and it can be change if the time or situation push it to be change.

\section{Culture and Language}

Condon (1973) in (Kuo \& Lai, 2006), culture can be assign as a way of life. No matter where people. That statement say culture is make from the way how people life, or what habit that do by people in their life and change be culture. Because the culture is make from that ways its make culture is so fragile or can change follow the situation. That is traits of culture it self, if we don't have fell to keep culture the culture will be lost. The way of how human life is create from many dimension according to (Kuo \& Lai, 2006) say that culture is have many thickness, consist of ideas, customs, arts, tools and skills, that indicate a arrange of people in given measure time it is also the beliefs, material object and values that build our way of life. (Douglas

(2000) in (Kuo \& Lai, 2006)), say that language has four different dimension. There are: comprehension and production, nature and nurture, competence and performance and universal grammars.

From the explanation above researcher can find the true meaning of culture, some expert believe that culture has multifarious meaning According to (Roohul-Amini, 1989) say culture is has multifarious understanding and culture mean farming (p. 15). It is used in everyplace as urban culture, american culture, rural culture and etc. That statement is show that meaning of culture is depend from the type of the culture it self that make culture have multifarious meaning.

Multifarious meaning its happen because culture itself is make from behavior and it build with unconsciously. According to Edward Sapir (1956) in (Holtgraves et al., 2014) says culture is a system of habit and modes that based on unconsciousness, and culture can say culture it's because the society is accepted in among of citizen(people). According to (Rocher, 1972), an folklore, deem that "culture is connection of theory and awareness that accepted in society by the majority of people" (p. 142)

Other thing that accepted and not accepted by society is language, people or society use language for their communication activity. In reality culture and language is two thing that exist in society. Study that explain and discuss about language is linguistic. Linguistics is a language scientific course. It is a foundational discipline insense that it bridges the social sciences, the natural sciences, and the humanities (Harris, 1951in (Kuo \& Lai, 2006))

That statement mention before, language and culture is two important thing that exist in society. And its influence each other. (Sapir, 1921; Berlin and Kay, 1969 in (Holtgraves et al., 2014)) say language can be exist it is in the context of culture and mutually. the culture which not have at its midpoint the structure of normal and accepted language cannot survive.language influence by the culture is make change on the semantic scope, in case culture effect the language or language effect the culture or in other word, language can control on how people see the world. ((Whorf, 1956), (Lavinson, C, 2000), claim, that all human looks the world by them use by theirs mother language. Because their effected each other some believe that language is product of the culture itself and more than that . according to (Gleason \& H S Jr, 1961) languages are the symbols of the culture and not only the products, language is part of 
social institution, that can be shaping and being shaped by society (Armour-Thomas \& Gopaul-McNicol, 1998 in (Kuo \& Lai, 2006)).

From the theory above can be proofen that language is influence by culture itself. Language cannot be exist in a gap and there is an inevitable kinds of "displacement" at work among culture and language (Fairclough, 1989 in Kuo and Lai).In the terms of linguistic of relationship between language and culture is explored - the theory of language shaping the minds of the native speaker - and the speaker is influential on the language itself from the idea that conducted from culture (Whorf 1956, Sapir 1962, Gumperz \& Levinson 1996 in (Grote \& Linz, 2003)).

\section{Culture Affect Language}

People approved and know it because the adaptation has already becomes a part of citizens live that blended into the cultures (Allison \& Vining, 1999 in (Kuo \& Lai, 2006)). That statement show us that something can be accepted by society is because that thing is be a part of local culture. Word "maaf" that use by citizen in Indonesia for asking permission be a local culture of Indonesian people. That thing is be a local culture so it can be easy to influence the other language by the local culture its self.

Culture can so easy to be accepted by social because culture is believe and norm of society in their local environment. According to (Greey, 1994 in (Kuo \& Lai, 2006)) Culture also known as a learned system based on attitudes, acceptance and/or rules among a association of people. According to (Kuo \& Lai, 2006) Broad definitions of culture include traditional background, political home, gender, inability, race, sexual orientation, and beliefs. That theory is appearance and be evidence that Culture not only changes people's assessment and behaviour, but also affects people's language and behaviors and the culture of a society can be changed depending upon the language used.

\section{METHOD}

Methodology that use in this research for process the data is qualitative with descriptive design. Qualitative research is reasech that mostly using word, language and experience to process the data or explain the data rather than use statistic, numerical feature and measurements. according to (Polit \& Hungler 2004:716 in (Geng, 2009)) Descriptive research refers to research studies that have as their main objective the accurate portrayal of the characteristics of persons, situations or groups. Intrument that use in this research is observation. Researcher do observation when researcher is in teacher position, researcher do this observation to student of senior high school in Cimahi. The amount of class that use is to different class first is XI TPTU B and XI Mekatronika in one of senior high school on Cimahi. The amount of student that observe by researcher is about fifty student. In a range of time is about two month.

\section{RESULTS AND DISCUSSION}

\section{Results}

In this research, researcher do as teacher that teach in xi class of senior high school. In classroom activity, researcher find some phenomenon that is student use word " sorry" for in context for asking permission when they communicate with friend, or teacher. The data that can find when 
the researcher do observation is in form of utterance that use by student when they communicate.

1. Situation : student is asking permission to borrow something.

Expression : Sorry bro, can I borrow your pen?

Sorry bro you have pen ?

Both of expression that mention above is expression that use by student in class room when they asking permission to other friend if they want borrow something. Both of expression is use for often, in two month observation almost all time when student want borrow something they use word "sorry" for asking the permission.

2. Situation : student asking permission to go to toilet or go outside.

Expression : Sorry sir may I go to toilet?

Sorry sir may I go out?

Expression that show above is expression that use by student if they want go out or asking permission to go to toilet.

3. Situation : student interrupt teacher when teacher explain about material.

Expression : sorry sir can you repeat again?

Expression that appears above is expression that use by student in classroom activity when student want interrupt the teacher or friend, when discussion is happen or when teacher is explain the material.

\section{Discussion}

This research is to proof are student of senior high school in cimahi mostly use word sorry that word excuse me to asking permission. And to find are word "sorry" in conversation of student in senior high school still have semantic meaning that is word for asking apology or for asking permission.

From the data that take by observation that do by researcher, researcher find three common situation that student use word sorry first is situation when student asking permission to borrow something, student asking permission to go out or to go to toilet, and the situation when student want interrupt teacher when teacher explain material or interrupt other student when discussion is happen.

First, second, and third situation show expression that use by student is using word "sorry" this expression is actually wrong if student want asking permission because from semantic meaning word sorry is for asking apologize and asking sympathy not for asking permission. That other people know culture of Indonesian people that be local culture is people or in this case is student use word " maaf" when they want asking permission to borrow something. Based on theory this phenomenon is happen because the culture of Indonesian for use word "maaf " to asking permission is influence the English language.

In this phenomenon culture is affect the language, and make the semantic meaning of word sorry is change, on theory word sorry is use to asking apologize such as " im sorry", "sorry I 
hurt you", and other. When someone use word sorry its mean they do some mistake and asking apologize to other. So if student use word sorry for asking permission when they want borrow something, asking permission to go to toilet, or interrupt someone, is not show the mistake or wrong situation.

On that situation student show context that they want asking permission to other friend or teacher, in English language word that have meaning for asking permission is word "excuse me" not word "sorry". That show word that use by student is error, or I other word student is doing some error.

That make student use word sorry to asking permission is not just because culture effect but also student think use word sorry more polite than use word "excuse me". Because in Indonesian paradigm word " maaf" more polite than " permisi.

\section{CONCLUSION}

From the data that finding in this research, and after the researcher process the data, researcher take the conclusion that is Word "sorry" on conversation in student in senior high school in Cimahi is as mostly word for asking permission and not for expressing sympathy or apologize like should semantic meaning. Because the mostly word that use by student is word "sorry" than word "excuse me" to asking permission, that's happen its influence by Indonesian culture its self. This research proof that common word use by student is word "sorry" and this research is find that in conversation of student in class room activity word "sorry" is not in semantic meaning.

\section{ACKNOWLEDGMENTS}

This article was made with the ture information and true source.the result of the reaseach is made from deep analysis and true teori. Hard work, support form several people, and guidance from lecturer and several article related to this article in writing process oras the reference. The researcher say apologize if this article is not perfect, and thank you for all support and corporation form other in the process of the writing the article. Hopefully this article can be reference for other who want to make article or reseach related to language and culture.

\section{REFERENCES}

Geng, X. (2009). An analysis of the cultural phenomena in English and its translation. Asian Social Science, 5(12), 141-144.

Gleason, \& H S Jr. (1961). An Introduction to Descriptive Linguistics. New Delhi: Oxford and IBH.

Holtgraves, T. M., Kashima, Y., Kashima, E., \& Kidd, E. (2014). Language and Culture. The Oxford Handbook of Language and Social Psychology, 2(17), 230-235.

Kuo, M.-M., \& Lai, C.-C. (2006). Linguistics across Cultures: The Impact of Culture on Second Language Learning. Journal of Foreign Language Instruction, 1(1), 110 .

Levinson, S. C. (2000). Yélî Dnye and the theory of basic color terms. Journal of Linguistic Anthropology, 10(1), 3-55.

Linz, K. G. E. (2003). The influence of sign language iconicity on semantic conceptualization. From sign to signing, 3, 23. 
Rocher, G. (1972). A General Introduction to Sociology: A theoretical perspective. New york: St. Martin's Press.

Roohul-Amini, M. (1989). Outline of Culture. Tehran: Atar press.

Sirbu, A. (2015). The significance of language as a tool of communication. Scientific Bulletin" Mircea cel Batran" Naval Academy, 18(2), 405.

Whorf, B. L. (2012). Language, thought, and reality: Selected writings of Benjamin Lee Whorf. MIT press. 